\title{
Whole tree hydraulic conductance and water loss regulation in Quercus during drought: evidence for stomatal control of embolism?
}

\author{
H Cochard, N Bréda, A Granier \\ Unité d'écophysiologie forestière, Centre de Nancy, Inra, 54280 Champenoux, France
}

(Received 2 January 1995; accepted 19 June 1995)

\begin{abstract}
Summary - The water relations of 30-year-old Quercus petraea were studied for three consecutive growing seasons. Whole tree specific hydraulic conductances $(g L)$ were computed from sap flow densities $(d F) /$ leaf water potential $\left(\Psi_{\text {leaf }}\right)$ relationships. $g L$ was clearly reduced with the development of the drought. The decrease of $g L$ with $\Psi_{\text {predawn }}$ was of an exponential type, ie, high variations of $g L$ were found whereas $\Psi_{\text {predawn }}$ remained high and constant. These early variations of $g L$ were most probably located in the soil-root compartment of the SPAC because no loss of hydraulic conductivity due to xylem embolism was detected in the crown of the trees. Although $g L$ was reduced, $\Psi_{\text {midday }}$ remained nearly constant and above $-3 \mathrm{MPa}$ throughout the drought period because $d F_{\text {midday }}$ was also significantly reduced. As a consequence, a good linear relation was found between $d F_{\text {midday }}$ and $g L$. Xylem embolism significantly developed in the petioles and twigs of $Q$ petraea when $\Psi_{\text {midday }}$ became less than $-3 \mathrm{MPa}$. We argue that, because of changes in $g L, Q$ petraea progressively adjusted its water loss throughout the drought development with the effect of maintaining $\Psi_{\text {midday }}$ above the cavitation threshold. It is shown that if no water loss regulation had occurred, considerable tensions would have developed in the crown of these trees with predictable branch mortality due to runaway embolism.
\end{abstract}

Quercus petraea / drought / water relation / embolism / hydraulic conductance

Resumé - Conductance hydraulique totale et régulation des pertes en eau chez Quercus en période de sécheresse : preuve d'un contrôle stomatique du développement de l'embolie ? Les relations hydriques de chênes sessiles agés de 30 ans ont été étudiées pendant trois saisons de végétation consécutives. La conductance hydraulique spécifique totale $(\mathrm{gL})$ a été calculée à partir

Abbreviations: $F$ : water flow; $d F$ : sap flux density; $d F_{\text {midday }}$ and $d F_{\text {predawn }}: d F$ at midday and predawn, respectively; $g l$ : whole tree apparent hydraulic conductance; $g L$ : sapwood-area-specific $g l ; g_{\mathrm{s}}$ : stomatal conductance for $\mathrm{H}_{2} \mathrm{O} ; K$ : hydraulic conductivity of a xylem segment; $K_{\text {init }}$ : initial $K ; K_{\max }$ : $K$ at saturation; PLC: percent loss of conductivity; $\Psi$ : water potential; $\Psi_{\text {soil }}:$ soil $\Psi ; \Psi_{\text {xylem }}=$ xylem $\Psi ; \Psi_{\text {leaf }}$ : leaf $\Psi ; \Psi_{\text {midday }}$ and $\Psi_{\text {predawn }}: \Psi_{\text {leaf }}$ at midday and predawn, respectively. 
des relations densité de flux de sève $(\mathrm{dF}) /$ potentiel hydrique foliaire ( $\Psi_{\text {leaf }}$ ). Nous avons noté une nette réduction de $\mathrm{g} \mathrm{L}$ au cours du développement de la sécheresse. Exprimée en fonction du potentiel hydrique de base ( $\left.\Psi_{\text {predawn }}\right)$, la décroissance de $\mathrm{gL}$ a été de type exponentielle, c'est-à-dire que de fortes variations de $g L$ ont été observées alors que $\Psi_{\text {predawn était élevé et constant. Ces variations précoces }}$ de gL étaient probablement localisées dans le compartiment racines-sol du SPAC en raison du faible développement de l'embolie dans le xylème. Bien que $\mathrm{g} \mathrm{L}$ soit réduit, $\Psi_{\text {midday }}$ est resté constant et audessus de -3MPa tout au long de la sécheresse parce que $\mathrm{dF}_{\text {midday }}$ fut réduit de façon importante. En conséquence une relation linéaire fut mise en évidence entre $\mathrm{gL}$ et $\mathrm{dF}_{\text {midday. }}$ Le taux d'embolie se développe de façon significative dans le xylème des pétioles et des rameaux feuillés lorsque $\Psi_{\text {midday }}$ devient inférieur à $-3 \mathrm{MPa}$. Nous suggérons que, en raison des changements de $g L, Q$ petraea ajuste progressivement ses pertes en eau ce qui a pour effet de maintenir $\Psi_{\text {midday }}$ au dessus du seuil de cavitation. Nous montrons qu'en l'absence de régulation des pertes d'eau des tensions xylémiques considérables se développeraient dans le houppier avec pour conséquence probable une mortalité importante des branches due au phénomène d'emballement de l'embolie.

Quercus petraea / sécheresse / relations hydriques / embolie / conductance hydraulique

\section{INTRODUCTION}

The physiology of the stomata is probably one of the most complex issues in plant physiology (Hinckley and Braatne, 1994). At the interface between the plant and the atmosphere, their aperture actively controls both water loss and the $\mathrm{CO}_{2}$ uptake. The determinism of stomatal aperture and its function is still a matter of debate. Large stomatal conductances increase $\mathrm{CO}_{2}$ uptake and productivity but also increase water loss, which can be damaging for plants particularly under drought conditions. The reason for this damage is that both high water loss and soil drought induce leaf water deficits. This results from the mechanism of water movement in plants. Water moves from the soil to the leaves driven by a negative potential gradient. This movement is simply and, in most cases, satisfactorily, described by an 'Ohm's law analogy' (Van den Honert, 1948): the water flow $\left(F, \mathrm{~kg} \mathrm{~s}^{-1}\right)$ through a permeable segment (xylem conduits) causes a water potential drop ( $d \Psi$, $\mathrm{MPa}$ ) inversely proportional to the segment hydraulic conductance $(K): d \Psi=F / K$. Although the Ohm's law analogy is most applicable to a xylem segment, it has also been applied to the whole soil-plant water pathway:

$$
\Psi_{\text {soil }}-\Psi_{\text {leaves }}=F / g l \quad[1]
$$

where $g /$ is an apparent hydraulic conductance of a plant considered as a unique segment; $\Psi_{\text {soil }}$ is an averaged soil water potential; and $\Psi_{\text {leaves }}$, the averaged leaf water potential when the total flow through the plant is $F$. When $F$ is normalized by the sapwood area at breast height (sap flux den-

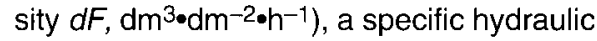
conductance $g L$ can be calculated. Equation [1] directly links the water losses, and therefore the stomatal aperture, to soil and leaf water deficits. The greater the water flow, the greater the water tension developed in the distal part of the sap pathway. Large water loss thus induces large water deficit in the leaves which may impair plant physiology. The situation is more critical under drought conditions because $\mathrm{g} /$ and $\Psi_{\text {soil }}$ are reduced, and a small water flow then induces very large leaf water deficit.

How water deficit affects tree physiology is a complex issue. A possible action, that has only recently been addressed, deals with the xylem dysfunction. Water deficits can induce xylem cavitation that disrupts sap transport to the leaves. If cavitations accumulate in the xylem, then the sap supply to the leaves can eventually stop, causing crown desiccation and mortality. Mod- 
els (Tyree and Sperry, 1988; Jones and Sutherland, 1991) suggest that stomata may play an important role in controlling the development of xylem embolism. Because cavitations develop when the xylem water potential becomes lower than a critical value (Sperry and Tyree, 1988), plants, by controlling their water losses, may maintain $\Psi_{\text {leaf }}$ above the critical value (see eq [1]).

The objective of this paper is to test the hypothesis that sap flow and water losses are regulated during drought according to changes in whole tree hydraulic conductance in order to avoid development of xylem embolism. To test the hypothesis, we reanalyzed our data from a 3 year survey of water relations of mature oak trees in a forest stand partially submitted to drought. These data have been published in several papers (Cochard et al, 1992; Bréda et al 1993a, b) and reviewed by Dreyer et al (1993). The main results will be summarized later but readers can refer to the papers just mentioned for more details.

The predawn and midday leaf water potentials declined progressively during the drought development. Water potentials as low as -2 and $-3.3 \mathrm{MPa}$ were measured at the end of the dry period at predawn and midday, respectively. Stomatal conductances and daily maximum sap flow densities were considerably reduced by drought. The most important changes were noted at the beginning of the drought, ie, when $\Psi_{\text {predawn }}$ and $\Psi_{\text {midday }}$ were still high. Whole tree apparent hydraulic conductance declined steeply at the beginning of the drought and then progressively during the development of the water shortage. These changes were reversible a few days after rehydration. Vulnerability curves established on petioles and 1-year-old twigs showed that the threshold water potential for cavitation is ca $-2.7 \mathrm{MPa}$ with $50 \%$ loss conductivity at $-3.3 \mathrm{MPa}$. Close to $100 \%$ loss of conductivity (PLC) was noted at $-4 \mathrm{MPa}$ (see fig 4). Although the minimum daily water potentials were very close to the threshold water potential inducing xylem embolism, the degree of embolism in petioles and the current year twigs remained low and increased significantly only at the end of the drought period when midday water potentials became lower than $-3 \mathrm{MPa}$.

\section{MATERIALS AND METHODS}

\section{Plant material and experimental plots}

Experiments were conducted from 1990 to 1992 on 35-year-old, $16 \mathrm{~m}$ high, $Q$ petraea trees in the Forest of Champenoux, near Nancy, in east France $\left(48^{\circ} 44^{\prime} \mathrm{N}, 6^{\circ} 14^{\prime} \mathrm{E}\right.$, altitude: $\left.237 \mathrm{~m}\right)$. Each year, two groups of four trees each were chosen, one from a control that was well-watered by periodic irrigation, and one from a dry plot. The dry plot was $5 \times 5 \mathrm{~m}$ in area, including about 15 trees, surrounded by a $1.4 \mathrm{~m}$ deep trench and covered by a watertight roof about $2 \mathrm{~m}$ above ground. At the end of the drought period, the plot was rewatered to field capacity. Two scaffolding towers gave access to the crown of the trees in each plot. A more thorough description of this site can be found in Bréda et al (1993b).

\section{Measurements}

Measurements took place during the growing seasons of the 3 consecutive years. Sap flow was continuously monitored by radial flow meters inserted in spring into the bole of the trees (Granier 1987). This device allows the measurement of the sap flux density $\left(d F,{d m^{3}}^{3} \cdot \mathrm{dm}^{-2} \cdot \mathrm{h}^{-1}\right)$ along a $2 \mathrm{~cm}$ deep radial axis. The total sap flux through the bole $\left(\mathrm{dm}^{-3} \cdot \mathrm{h}^{-1}\right)$ can be estimated by multiplying $d F$ by the sapwood area at the same height in the trunk. Leaf water potential was measured on two to five leaves per tree with a pressure chamber. Leaves were sampled on a weekly basis in the crown just prior to dawn (predawn water potential, $\Psi_{\text {predawn }}$ ) and at 1300 hours solar time (midday water potential, $\Psi_{\text {midday }}$ ). Daily courses of leaf water potential were also performed occasionally. Midday stomatal conductances, $g_{\mathrm{s}}$, were measured on a weekly basis with a Li-Cor 1600 
porometer (Li-Cor Inc, Lincoln, NE, USA) on five to ten sun-exposed leaves from different branches of the upper half crown of each tree. Whole tree specific apparent hydraulic conductances, $g L$, were estimated by the slope of the $d F / \Psi_{\text {leaf }}$ daily regressions. These regressions were based on five to six points. $g L$ was also calculated with a 'single-point' method according to the equation:

$$
\begin{gathered}
g L=-{ }^{*}\left(d F_{\text {predawn }}-d F_{\text {midday }}\right) / \\
\left(\Psi_{\text {predawn }}-\Psi_{\text {midday }}\right)
\end{gathered}
$$

where $d F_{\text {predawn }}$ and $d F_{\text {midday }}$ are the whole steady-state sap flow density through the tree at predawn (usually 0) and midday, respectively; $\Psi_{\text {predawn }}$ and $\Psi_{\text {midday }}$ are the average leaf water potentials at the same time. Initial results demonstrated that the two methods yielded similar results $\left(n=28, r^{2}=0.84\right.$, slope $=1.1$, not statistically different from 1 at $P=0.05$ ) (fig 1 ). The second method being much less time consuming, most $g L$ values shown in this paper were therefore computed with the predawn and midday values of $d F$ and $\Psi$ only. Days corresponding to incomplete leaf area expansion (late spring) or to heavily clouded days (Iow PET) were removed from the data set. Vulnerability of xylem conduits to embolism induced by water stress was assessed in 1-year-old twigs and petioles via the effect of cavitation on loss of hydraulic conductivity (Sperry et al, 1988). The procedure is described in detail by Cochard et al (1992). In short, 2- to 4-year-old branches were cut from the crown of control trees, brought to the laboratory and bench dehydrated. When branches reached a leaf water potential between -1 and $-5 \mathrm{MPa}$, they were rehydrated for $30 \mathrm{~min}$ to reduce xylem tensions and 15 samples, $2-3 \mathrm{~cm}$ long, were excised under water. The initial hydraulic conductivity $\left(K_{\text {init }}, \mathrm{kg} \mathrm{m} \mathrm{s}^{-1} \mathrm{MPa}^{-1}\right)$ was calculated by measuring the water flow through each sample $\left(\mathrm{kg} \mathrm{s}^{-1}\right)$ when perfused with a $6 \mathrm{kPa}$ head of distilled water. The maximum conductivity, $K_{\max }$, was measured the same way after the samples had been perfused at $0.1 \mathrm{MPa}$ for $20 \mathrm{~min}$. The percent loss of conductivity was then computed as:

$$
\mathrm{PLC}=100^{*}\left(1-K_{\text {init }} / K_{\max }\right)
$$

The natural development of embolism was measured with the same technique on branches excised from the upper crown of each tree throughout the growing season.

\section{RESULTS AND DISCUSSION}

\section{Hydraulic conductance and water loss}

In figure 2, we represented for one representative drought tree and one control tree the seasonal patterns of the daily water potential/sap flow density relationships. By definition, the slope of these curves represent the whole tree apparent hydraulic conductance. In Quercus petraea, these relations were, in most cases, linear, indicating that the flow was always close to steady state (low tree capacitance) and that $g L$ did not change during the day. It was therefore possible to compute $g L$ values with flow/potential relationships. The sap flow has been found to be proportional to the water potential gradient in many species

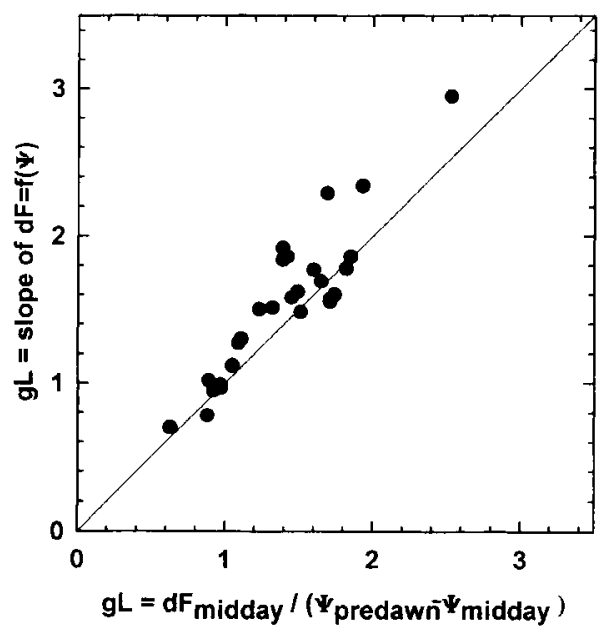

Fig 1. Techniques to assess whole tree specific hydraulic conductances $(g L)$. $g L$ was calculated either as the slope of a linear regression between the daily variations in leaf water potential $(\Psi)$ and sap flow density ( $d F)$ ( $y$-axis) or as the ratio between the daily maximum flow density $\left(\mathrm{dF}_{\text {mid- }}\right.$ day) and difference between the predawn and minimum leaf water potentials $\left(\Psi_{\text {predawn }}-\Psi_{\text {mid- }}\right.$ day). The two techniques yielded similar results $\left(r^{2}=0.84\right.$, slope not different from 1 at $P=0.05$ ). The latter method was preferred for its simplicity. 
(Waring and Running, 1978; Cohen et al, 1983; Küppers, 1984; Reich and Hinckley, 1989; Granier and Colin, 1990) although earlier theoretical and experimental data also suggested nonlinear relations due to variable $g L$ (Passioura, 1984). It can be seen that the relations remained unchanged for the control tree and that the maximum flow densities were comparable for the different days. The maximum transpiration rate was therefore not limited by climatic conditions for these days. For the stressed tree, drought induced a progressive drop of $\Psi_{\text {predawn }}$ (intercept on the $x$-axis) and to a lesser extent, $\Psi_{\text {midday }} g L$ was significantly reduced by drought. These variations were most likely located at the soil-root interface because $g L$ came back to predrought values after rehydration and embolism developed in the petioles and twigs long after $g L$ declined. Nevertheless, we cannot exclude embolism formation in the roots that may be more vulnerable than twigs (Sperry and Saliendra, 1994). $d F_{\text {midday }}$ was considerably reduced during drought because of partial stomatal closure. Therefore, the changes in maximum sap flow densities occurred according to changes in $g L$ and the conse- quence was that the minimum water potentials always remained above ca $-2.8 \mathrm{MPa}$.

Because the variations in $\Psi_{\text {predawn }}-\Psi_{\text {mid- }}$ day were limited during the drought, one should expect a relationship between the maximum sap flow density and $g L$. In figure 3 , we plotted this relationship for our complete data set, ie, including data based on the single-point method. The relation found between these two variables was significant ( $r=0.76, n=178)$ and linear. The maximum transpiration rate is therefore correlated in Quercus petraea with the whole tree apparent hydraulic conductance. Correlation between water loss (or stomatal conductance) and hydraulic conductances have been reported for many herbaceous and ligneous species (Reich and Hinckley, 1989; Meinzer and Grantz, 1990; Brisson et al, 1993; Sperry and Pockman, 1993). These results suggest that water loss is permanently adjusted to the water transport capacity of a plant.

Two major questions arise from this behavior: i) what are the mechanisms triggering the stomatal closure, and ii) what are the functions of the stomatal regulation?
Fig 2. Typical summer pattern for the daily variations of sap flux density $(d F)$ and leaf water potential $\left(\Psi_{\text {leaf }}\right)$ for one control tree (closed symbols) and one waterstressed tree (open symbols). Different symbols correspond to different days. Error bars are one standard deviation. The variations were in most cases close to linearity which validated the computation of $g L$ as reverse of the slope of these lines. $g L$ remains constant along the summer whereas it was clearly reduced by drought. Although $g L$ was reduced, the minimum daily water potentials remained above -2.8 $\mathrm{MPa}$ (dashed lines) due to a simultaneous reduction in the daily maximum sap flow density.

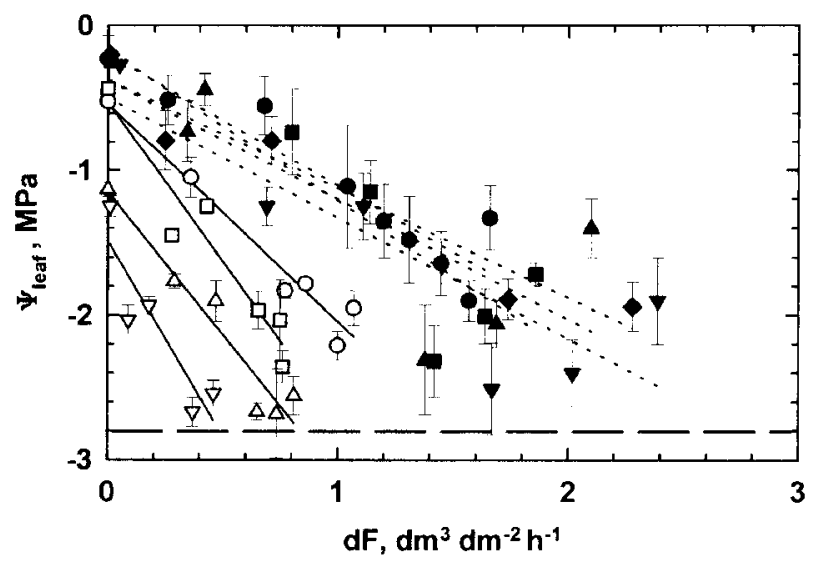




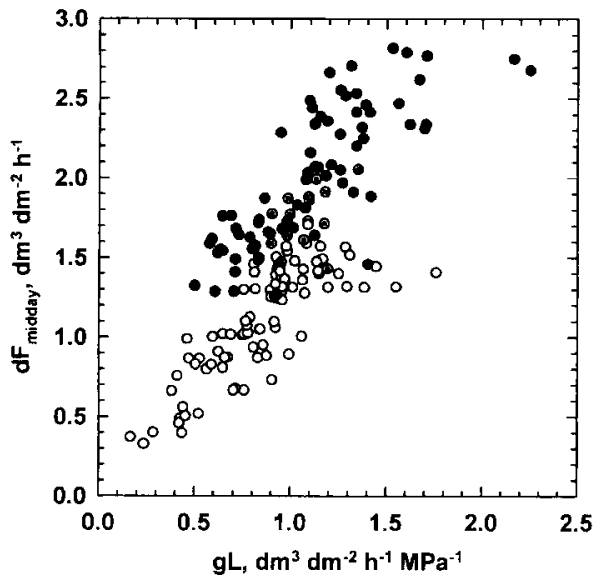

Fig 3. Daily maximum sap flow density ( $d F_{\text {mid- }}$ day) versus concurrent whole tree hydraulic conductance $(g L)$ for control (closed circles), stressed (open circles) and rehydrated trees (dotted circles). $d F_{\text {midday }}$ and $g L$ were found to decrease linearly, which suggested that $d F_{\text {midday }}$ was limited by the reduction in $g L$. After rewatering, $g L$ and $d F_{\text {midday }}$ came back to predrought conditions, indicating the reversibility of the phenomenon.

Stomata have long been supposed to respond to hydraulic signals caused by a decrease in leaf water potential, but more recent studies (Gollan et al, 1986; Zhang and Davies, 1989; Tardieu et al, 1992) have revealed the role of specific hormones (ABA) in the control of $g_{\mathrm{S}}$ during drought. Roots in the dry zones of the soil are producing ABA that provoke stomatal closure. An argument in favor of hormonal signals is that the stomatal conductance can be reduced independently of changes in leaf water status. This is the case in the first stage of a drought period (see earlier) or in split-root experiments (experiments where the roots are split into two compartments with different water regimes). In both situations, although the leaf water status is unchanged, the hydraulic functioning of the tree is largely modified due to large changes in $g L$. An hydraulic triggering signal for stomatal closure may still exist in plants (Malone, 1993).
Meinzer and Grantz (1990) addressed this issue in sugarcane. They suggested that the stomata respond to changes in $g L$ via a possible effect of $g L$ on the ABA production in the roots. Tardieu and Davies (1993) also proposed that in maize the sensitivity of the stomata to ABA depends on the current leaf water potential. Sperry and Pockman (1993) demonstrated that in Betula, stomata were also capable of reacting to changes in hydraulic conductances located only in branches, thus with constant root water status conditions. Clearly, the mechanisms of stomatal response to changes in $g L$ deserve further study, and integration of both hydraulic and hormonal signals should be considered.

\section{Stomatal control of embolism}

The second issue may even be more puzzling for the physiologists. What limits the water losses of an oak tree during drought? The most often cited explanation is that critical tissue desiccation caused by low water potentials is what stomatal regulation has evolved to avoid. Tissue desiccation causes loss of turgor in the living cells which may impair growth and plant survival. In the short term, desiccation may cause xylem cavitation (Tyree and Sperry, 1988) and also compromise tree survival. The vulnerability to cavitation puts a functional limit to the xylem transport capacity. Any cavitation event reduces the xylem hydraulic conductivity and thus impairs the water transport to the leaves. Use of simple models (Tyree and Sperry, 1988) has shown that trees function close to the point of catastrophic xylem failure due to runaway embolisms. If the transpiration rate remains constant, then any decrease in xylem conductivity will decrease the water potential which causes further cavitation events and so on, until all the conduits are embolized. If this phenomenon occurs, then we can predict rapid desiccation 
and eventually the death of the tissues situated apically from these xylem conduits. In this study, we did not determine the theoretical point of runaway embolism in the sense of Tyree and Sperry (1988) or Jones and Sutherland (1991), but we considered the point of xylem dysfunction, ie, when the degree of xylem embolism becomes significantly higher than the native state level. Our data on Quercus petraea revealed that this point corresponds to a xylem water potential ( $\Psi_{\text {xylem }}$ ) of ca $-2.5 \mathrm{MPa}$ (fig 4). Because of large leaf-blade resistance in oaks (Tyree et al, 1993) $\Psi_{\text {leaf }}$ underestimates $\Psi_{\text {xylem }}$, depending on the evaporative flux density. We estimated that when $\Psi_{\text {leaf }}=-2.8 \mathrm{MPa}$, $\Psi_{\text {xylem }}$ is close to the point of xylem dysfunction $(-2.5 \mathrm{MPa})$. The fact that $\Psi_{\text {leaf }}$ remained for a very long period above -2.8 $\mathrm{MPa}$ because $d F_{\text {midday }}$ was reduced (fig 2) and that $g_{\mathrm{s}}$ was less than $10 \%$ of its maximal values when $\Psi_{\text {midday }}$ was close to $-2.8 \mathrm{MPa}$ (fig 4) suggested to us that in Quercus petraea the stomatal closure is protecting the xylem from embolism development. To

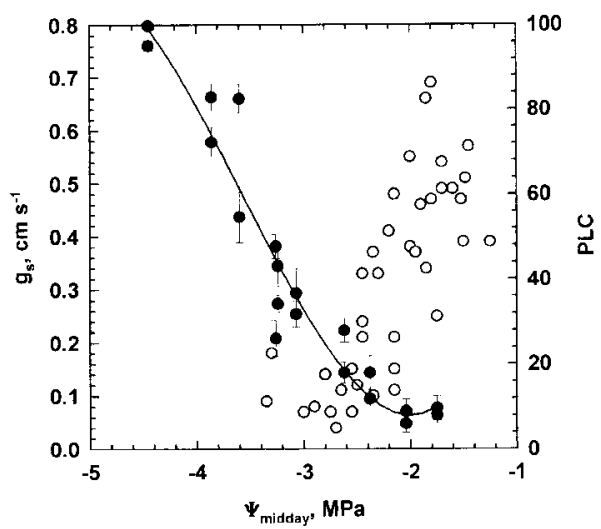

Fig 4. Percent loss hydraulic conductivity (PLC) due to xylem embolism (closed circles) and midday stomatal conductance $\left(g_{S}\right)$ (open circles) versus leaf water potential at midday ( $\left.\Psi_{\text {midday }}\right)$. Vertical error bars represent one standard deviation. Embolism significantly increased in petioles and twigs when $\Psi_{\text {leaf }}$ became lower than $-2.7 \mathrm{MPa}$, the point where the $g_{\mathrm{s}}$ was reduced to about $10 \%$ of its maximal value. explore this hypothesis, we constructed a simple model relating $d F$ to $g L$ and $\Psi$ based on equation [1]:

$$
d F_{\text {cavitation }}=g L^{\star}\left(\Psi_{\text {predawn }}-\Psi_{\text {cavitation }}\right)
$$

where $d F_{\text {cavitation }}$ is the critical maximum sap flow density that for any given values of $\Psi_{\text {predawn }}$ and $g L$ induced a minimum leaf water potential equal to the point of xylem dysfunction ( $\Psi_{\text {cavitation }}=-2.8 \mathrm{MPa}$ ). In figure 5 , we plotted the relationship between the actual $d F_{\text {midday }}$ and the predicted $d F_{\text {cavita- }}$ tion. It is clear from this graph that $d F_{\text {midday }}$ was in all cases very close to $d F_{\text {cavitation, }}$ indicating that trees were operating close to the point of xylem dysfunction. As drought developed, $d F_{\text {cavitation }}$ decreased because both $\Psi_{\text {predawn }}$ and $g L$ decreased; nevertheless, $d F_{\text {midday }}$ was adjusted and remained below $d F_{\text {cavitation }}$ for most of the trees. We computed that for the driest trees, the dif-

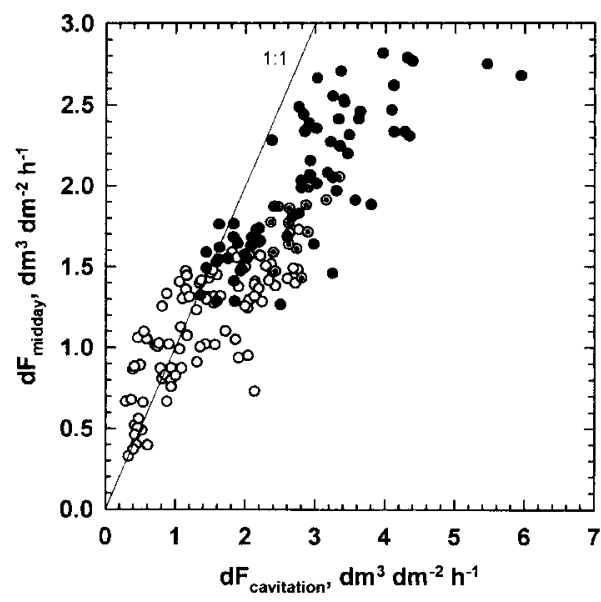

Fig 5. Actual midday sap flow density ( $\left.d F_{\text {midday }}\right)$ versus theoretical sap flow density ( $\left.d F_{\text {cavitation }}\right)$ inducing xylem embolism (see text for details). Symbols as in figure $3 . d F_{\text {midday }}$ was found close to $d F_{\text {cavitation, suggesting that the trees were func- }}$ tioning close to the point of xylem dysfunction. As drought developed, $d F_{\text {midday }}$ was reduced but remained for a long time below $d F_{\text {cavitation. }}$. Only at the end of the drought period did $d F_{\text {midday }}$ became higher than $d F_{\text {cavitation }}$. 
ference between $d F_{\text {midday }}$ and $d F_{\text {cavitation }}$ represented less that a few percent of the $d F_{\text {midday }}$ of the control trees. It can be noted that for some droughted trees, $d F_{\text {midday }}$ became higher than the predicted $d F_{\text {cavita- }}$ tion. Xylem embolism should occur under these conditions according to our hypothesis. Our seasonal survey of xylem embolism revealed that cavitation drastically developed only in trees that did not maintain $\Psi_{\text {mid- }}$ day above $\Psi_{\text {cavitation (positive } x \text { values in fig }}$ 7). Stomata may not be able to respond to changes in $g L$ after a prolonged period of drought, as suggested by Sperry and Pockman (1993).

A second way to illustrate the critical role of the stomata in the control of xylem embolism is to compute a theoretical minimum water potential, $\Psi_{\text {min }}$, that would occur if the no regulation took place, ie, if the transpiration of the stressed trees was set equal

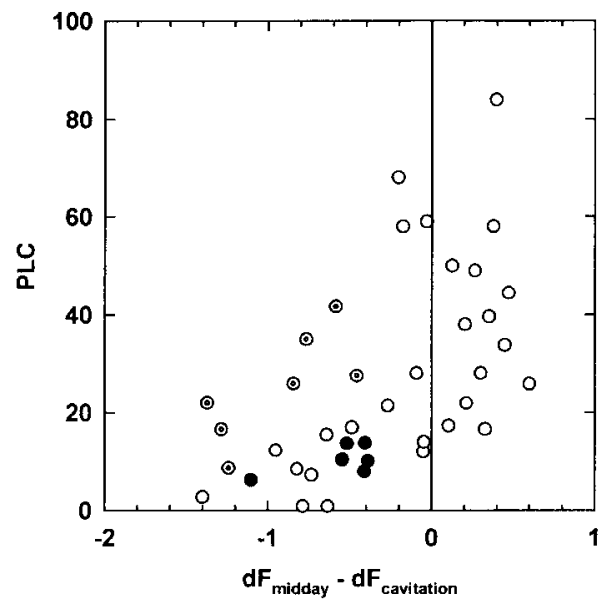

Fig 6. Measured degree of embolism in petioles versus difference between actual $d F_{\text {midday }}$ and calculated $d F_{\text {cavitation }}$. Symbols as in figure 3 . According to our model, when $d F_{\text {midday }}$ becomes higher than $d F_{\text {cavitation }}$ (positive values on $x$-axis), then embolism should develop. Our predictions are consistent with the measured degrees of embolism. Note that due to the irreversibility of embolism in oak, PLC in rehydrated trees remained high although $d F_{\text {midday }}$ became lower than $d F_{\text {cavitation }}$ after rehydration. to the transpiration of the control trees $\left(d F_{\text {control }}\right)$ all through the drought period:

$$
\Psi_{\text {min }}=\Psi_{\text {predawn }}-d F_{\text {control }} / g L
$$

In figure 7, we expressed $\Psi_{\min }$ and $\Psi_{\text {midday }}$ as a function of $g L$. It is clear from this graph that considerable tensions would have occurred in the leaf xylem of the drought trees in the absence of regulation. We can thus predict that because of these tensions and because of runaway embolism, the degree of embolism would have soon reached $100 \%$. Throughout these 3 consecutive years, stomatal closure in Quercus pertraea contributed to the maintenance of xylem integrity and protection against damage caused by vessel cavitation. This behavior probably enhances the fitness and the survival of this species.

\section{CONCLUSION}

Many authors have already pointed out the apparent correlation between the stomatal

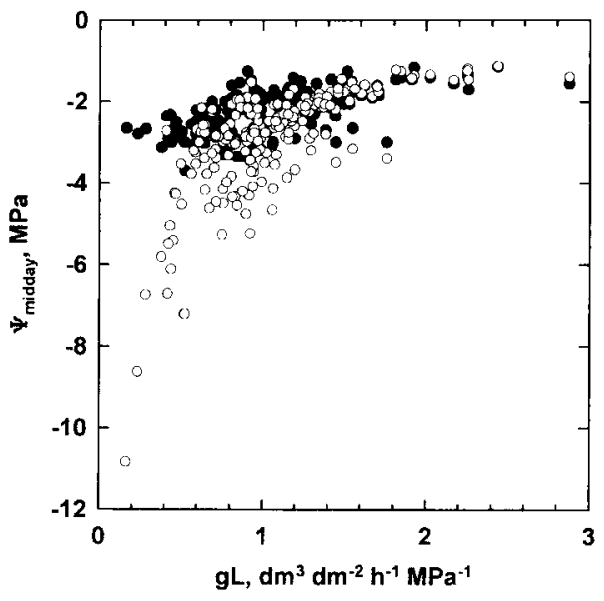

Fig 7. Actual (closed circles) and theoretical (open circles) midday leaf water potentials $\left(\Psi_{\text {midday }}\right)$ versus $g L$. The theoretical $\Psi_{\text {leat }}$ is the potential that would be generated in the absence of water loss regulation. 
conductance and the water transport capacity of a plant. In this paper, we give further evidence for this co-functioning in Quercus petraea, but we further argue that this regulation plays a major role in controlling the development of xylem embolism by maintaining the minimum water potential above the threshold potential for xylem dysfunction. The maximum theoretical sap flow density and thus the degree of stomatal regulation in Quercus petraea can therefore be inferred from the water transport capacity of the whole tree $(g L)$ and the xylem vulnerability to embolism induced by water stress. The mechanisms of stomatal response to change in hydraulic conductance is unknown and may involve both an hormonal and an hydraulic signal. Whatever the mechanism, our data demonstrate that it is extremely accurate because any minor deviation from the actual flow value would have led to catastrophic xylem dysfunction. Data on the hydraulic functioning and dysfunctioning of plants may therefore generate significant progress in the understanding of whole tree water relations.

\section{ACKNOWLEDGMENTS}

We are grateful to $B$ Clerc and F Willm for technical assistance and to $P$ Gross for setting up the electronic equipment. We thank $E$ Dreyer and two anonymous reviewers for improving our initial manuscript. This work was partly supported by an European Community project (STEP CT900050).

\section{REFERENCES}

Bréda N, Cochard H, Dreyer E, Granier A (1993a) Field comparison of transpiration, stomatal conductance and vulnerability to cavitation of Quercus petraea and Quercus robur under water stress. Ann Sci For $50,571-582$

Bréda N, Cochard H, Dreyer E, Granier A (1993b) Water transfer in a mature oak stand (Quercus petraea): seasonal evolution and effects of a severe drought. Can J For Res 23, 1136-1143
Brisson N, Olioso A, Clastre P (1993) Daily transpiration of field soybeans as related to hydraulic conductance, root distribution, soil potential and midday leaf potential. Plant Soil 154, 227-237

Cochard H, Bréda N, Granier A, Aussenac G (1992) Vulnerability to air embolism of three European oak species (Quercus petraea (Matt) Liebl, Q pubescens Willd, $Q$ robur $L$ ). Ann Sci For 49, 225-233

Cohen Y, Fuchs M, Cohen S (1983) Resistance to water uptake in a mature Citrus tree. J Exp Bot 141, 451460

Dreyer E, Granier A, Bréda N, Cochard H, Epron E, Aussenac $G$ (1993) Oak trees under drought constraints: ecophysiological aspects. In: Recent Advances in Studies on Oak Decine (N Luisi, P Lerario, A Vannini, eds), Univ Bari, Italy

Gollan T, Passioura JB, Munns R (1986) Soil water status affects the stomatal conductance of fully turgid wheat and sunflower leaves. Aust J Plant Physiol $13,459-464$

Granier A (1987) Evaluation of transpiration in a Douglasfir stand by means of sap flow measurements. Tree Physio/3, 309-320

Granier A, Colin F (1990) Effets d'une sécheresse édaphique sur le fonctionnement hydrique d'Abies bornmulleriana en conditions naturelles. Ann Sci For 47, 189-200

Hinckley TM, Braatne JH (1994) Stomata. Plant Environ Interact 323-355

Jones HG, Sutherland RA (1991) Stomatal control of xylem embolism. Plant Cell Environ 14, 607-612

Küppers M (1984) Carbon relations and competition between woody species in a Central European hedgerow. II. Stomatal responses, water use, and hydraulic conductivity in the root/leaf pathway. Oecologia 64, 344-354

Malone M (1993) Hydraulic signals. Phil Trans $R$ Soc $B$ (Lond) 341, 33-39

Meinzer FC, Grantz DA (1990) Stomatal and hydraulic conductance in growing sugarcane stomatal adjustment to water transport capacity. Plant Cell Environ 13, 383-388

Passioura JB (1984) Hydraulic resistance of plants. I. Constant or variable? Aust J Plant Physiol 11, 333-339

Reich PB, Hinckley TM (1989) Influence of pre-dawn water potential and soil-to-leaf hydraulic conductance on maximum daily leaf diffusive conductance in two oak species. Funct Eco/3, 719-726

Sperry JS, Tyree MT (1988) Mechanism of water stressinduced xylem embolism. Plant Physiol 88, 581-587

Sperry JS, Pockman WT (1993) Limitation of transpiration by hydraulic conductance and xylem cavitation in Betula occidentalis. Plant Cell Environ 16, 279-287

Sperry JS, Saliendra NZ (1994) Intra- and inter-plant variation in xylem cavitation in Betula occidentalis. Plant Cell Environ 17, 1233-1241 
Sperry JS, Donnelly JR, Tyree MT (1988) A method for measuring hydraulic conductivity and embolism in xylem. Plant Cell Environ 11, 35-40

Tardieu F, Davies WJ (1993) Integration of hydraulic and chemical signaling in the control of stomatal conductance and water status of droughted plants. Plant Cell Environ 16, 341-349

Tardieu F, Zhang J, Katerji N, Bethenod O, Palmer S, Davies WJ (1992) Xylem ABA controls the stomatal conductance of field-grown maize subjected to soil compaction or soil drying. Plant Cell Environ 15 , 193-197

Tyree MT (1988) A dynamic model for water flow in a single tree: evidence that models must account for hydraulic architecture. Tree Physio/ 4, 195-217

Tyree MT, Sperry JS (1988) Do woody plants operate near the point of catastrophic xylem dysfunction caused by dynamic water stress? Answers from a model. Plant Physiol 88, 574-580

Tyree MT, Sperry JS (1989) Vuinerability of xylem to cavitation and embolism. Ann Rev Plant Physiol Mol Biol 40, 19-38

Tyree MT, Sinclair B, Lu P, Granier A (1993) Whole shoot hydraulic resistance in Quercus species measured with a new high-pressure flowmeter. Ann Sci For 50, 417-423

Van den Honert TH (1948) Water transport in plants as a catenary process. Disc Farad Soc 3, 146-153

Waring $\mathrm{RH}$, Running SW (1978) Sapwood water storage: its contribution to transpiration and effect upon water conductance through the stems of old-growth Douglas-fir. Plant Cell Environ 1, 131-140

Zhang J, Davies WJ (1989) Abscisic acid produced in dehydrating roots may enable the plant to measure the water status of the soil. Plant Cell Environ 12, 73-81 